\title{
Pengaruh Keteraturan Membaca dan Penghayatan Makna Ayat Al-Qur'an pada Kemampuan Berpikir Positif Narapidana
}

\section{The Impact of Reading on Regular Basis and Comprehending Meaning Al-Qur'an Training to Increase Positive Thinking Ability of Prisoners}

\author{
Aida Dakhliyah Sufriani \\ R.A. Retno Kumolohadi* \\ Fakultas Psikologi dan IImu Sosial Budaya UII, Yogyakarta 88854 \\ Diterima 1 Maret 2009 / Disetujui 20 Mei 2009
}

\begin{abstract}
This study is aimed to examine the impact of reading on the regular basis and comprehending Al-Qur'an training to increase positive thinking ability. The hypothesis of this research is that there is, a positive correlation between the training and positive thinking ability. The prisoners who followed training had more positive thinking ability. There are twenty prisoner from Yogyakarta Penintentiary Class IIA that were involved in the research. Many aspects from Albrecht conception were used to make 50 items scale. Pre-post test control group design is the experimental design of this research. From quantitative analysis SPPS Program version 11,5 for windows, researcher obtain scores between two groups $(p=0.0125 ; p<0.05)$, therefore the hypothesis is accepted.
\end{abstract}

Keywords : positive thinking, reading an the regular bases, meaning Qur'an

Menurut Undang-Undang Republik Indonesia Nomor 12 Tahun 1995 Tentang Pemasyarakatan (Priyatno, 2006), yang dimaksud dengan narapidana adalah terpidana yang menjalani pidana hilang kemerdekaan di Lembaga Pemasyarakatan, sedangkan narapidana adalah seseorang yang dipidana berdasarkan putusan pengadilan yang telah memperoleh kekuatan hukum tetap.

Sebagian besar masyarakat mengganggap narapidana adalah orang-orang yang terbuang, divonis sebagai pesakitan yang memang pantas berada di balik terali besi (www.ditjenpas.go.id, 31/05/08). Stigma negatif itu tampaknya melekat kuat di dalam benak sebagian masyarakat ketika menyebut kata narapidana, padahal fakta yang terjadi tidak semuanya benar. Ketika kembali ke dalam lingkungan masyarakat, narapidana merasa

\footnotetext{
* Penulis Korespondensi :

Telp. 0274 - 898444, HP. 08562864969 Email : kumolohadiretno@yahoo.com
} 
disisihkan dari ruang pergaulan (baitulmaalhidayatullah.com, 06/05/08). Adanya stigma negatif tentang mantan narapidana karena banyak mantan narapidana yang mengulangi kesalahannya.

Bagi para narapidana, Lembaga Pemasyarakatan boleh jadi merupakan tempat yang tepat untuk pembinaan rohani. Hal ini dikarenakan selama tinggal di Lembaga Pemasyarakatan narapidana berada di tempat yang terisolasi, jauh dari sanak keluarga dan teman-teman. Kehidupan sehari-hari hanya menunggu masa berakhirnya hukuman dan pada saat-saat seperti ini, banyak waktu untuk merenung serta menyesali kesalahan masa lalu. Dengan kata lain, agama menjadi "pelarian" bagi banyak narapidana (www.hamline.edu, $31 / 05 / 08)$.

Pikiran-pikiran negatif narapidana dalam menghadapi masa bebasnya karena tidak dapat terpenuhi kebutuhan, harapan dan berbagai kemungkinan gagal lainnya dapat diatasi dengan penyerahan diri kepada Allah SWT dan berbuat baik (Zuhroni dkk., 2003). Sendiony (Hawari, 2002) menambahkan bahwa pengalaman beragama (Islam) dapat meningkatkan derajat kesejahteraan seseorang, bebas dari pikiran negatif, stres, cemas dan depresi (a state of well being). Membaca dan menghayati makna ayat dalam Al-Quran mengandung unsur spiritual (kerohanian/keagamaan) yang dapat membangkitkan harapan, rasa percaya diri dan optimisme.

Narapidana dapat lebih positif dalam berpikir ketika dirinya terlibat dalam kegiatankegiatan keagamaan. Albrecht (2005) mengartikan berpikir positif sebagai perhatian yang tertuju pada subjek positif dan menggunakan bahasa positif untuk membentuk dan menggunakan pikiran. Perhatian positif berarti pemusatan perhatian pada hal-hal dan pengalaman-pengalaman yang positif sedangkan bahasa positif adalah penggunaan katakata ataupun kalimat yang positif untuk mengekspresikan isi pikirannya. Individu yang berpikir positif akan lebih sering berbicara tentang kesuksesan daripada kegagalan, cinta daripada kebencian, kebahagiaan daripada kepedihan, persahabatan daripada permusuhan, rasa percaya diri daripada rasa takut, kepuasan daripada ketidakpuasan, kebaikan daripada kejahatan, dan berita yang baik daripada yang buruk serta bagaimana memecahkan masalah.

Albrecht (2005) menjelaskan pengertian berpikir positif sebagai perhatian positif dan verbalisasi positif. Aspek berpikir positif ini meliputi :

a. Perhatian positif.

1) Konsep diri positif, yaitu individu mengganti berita buruk dengan berita baik.

2) Keberhasilan, yaitu individu mengganti kegagalan dengan ide keberhasilan.

3) Rencana dan harapan, yaitu individu mengganti ketakutan dengan pengharapan, dan 
frustrasi dengan ide baru untuk masa mendatang.

4) Jalan keluar, yaitu individu mengganti kekhawatiran akan masalah yang dihadapi dengan gagasan jalan keluar.

b. Verbalisasi positif.

1) Pemantapan diri, yaitu individu memusatkan perhatian pada kekuatan diri, melihat diri secara positif, serta menggantikan kritik diri dan menyalahkan diri dengan kemantapan diri.

2) Pembicaraan non evaluatif, yaitu pernyataan yang lebih menggambarkan keadaan daripada menilai keadaan. Pernyataan ataupun penilaian ini dimaksudkan sebagai pengganti pada saat seseorang cenderung memberikan pernyataan atau penilaian yang negatif. Aspek ini akan sangat berperan dalam menghadapi keadaan yang cenderung negatif.

3) Adaptasi terhadap realita dan harapan, yaitu mengakui kenyataan dan segera berusaha menyesuaikan diri dari penyesalan, frustrasi dan menyalahkan diri.

4) Keinginan positif, yaitu dalam menyampaikan suatu hal lebih dipusatkan pada hal yang positif. Individu yang berpikir positif mempunyai harapan dan cita-cita yang positif, misalnya harapan akan sukses

Pembentukan berpikir positif diharapkan dapat dilakukan dengan berbagai cara, salah satunya adalah dengan keteraturan membaca dan memaknai ayat Al Qur'an. Aspek keteraturan menurut Kamus Besar Bahasa Indonesia berarti:

a. Dilakukan secara konsisten, walaupun terdapat hambatan.

b. Dilakukan secara teratur atau sesuai dengan jadwal.

c. Dilakukan secara berkesinambungan atau berkelanjutan.

Kegiatan keberagamaan yang dilakukan dalam bentuk pelatihan ini, relevan dengan Peraturan Pemerintah Republik Indonesia Nomor 31 Tahun 1999 Tentang Pembinaan dan Pembimbingan Warga Binaan Pemasyarakatan (Priyatno, 2006). Pembinaan adalah kegiatan untuk meningkatkan kualitas ketaqwaan kepada Tuhan Yang Maha Esa, intelektual, sikap dan perilaku, profesional, kesehatan jasmani dan rohani narapidana dan anak didik pemasyarakatan.

\section{Metode Penelitian}

\section{Subjek Penelitian}

Subjek dalam penelitian ini adalah 20 orang narapidana yang sedang menjalani hukuman di Lembaga Pemasyarakatan Kelas II A Yogyakarta. Pengambilan subjeknya ditentukan oleh pihak Lembaga Pemasyarakatan Kelas II A Yogyakarta. Subjek penelitian 
dirandom menjadi dua kelompok yaitu 10 subjek kelompok eksperimen dan 10 subjek kelompok kontrol. Kriteria subjek yang ditetapkan untuk mencapai tujuan penelitian adalah sebagai berikut :

1. Jenis kelamin laki-laki.

2. Beragama Islam.

3. Bisa membacaAl-Quran minimal tingkat marhalah ula.

4. Usia berkisar antara 23 tahun sampai dengan 53 tahun.

5. Lama masa hukuman minimal enam bulan.

6. Bukan residivis

\section{Rancangan Penelitian}

Pelaksanan penelitian eksperimen ini dengan model Rancangan Prates - Pascates dengan Kelompok Kontrol (Pretest-Posttest with Control Group Design). Caranya adalah melakukan pengukuran sebelum dan sesudah perlakuan keteraturan membaca dan menghayati makna ayat dalam Al-Quran. Subjek dibedakan menjadi kelompok eksperimen dan kelompok kontrol. Kelompok eksperimen mendapatkan perlakuan keteraturan membaca dan menghayati makna ayat dalam Al-Quran, sedangkan kelompok kontrol mendapatkan plasebo berupa penyuluhan.

\section{Pengumpulan Data}

Metode pengumpulan data yang digunakan dalam penelitian ini menggunakan Skala Berpikir Positif. Skala Berpikir Positif dibuat dengan cara memodifikasi Skala Berpikir Positif yang telah dibuat oleh Rahayu (2004) berdasarkan aspek perhatian positif yang dikemukakan oleh Albrecht (2005), yang telah disesuaikan dengan konsep dan dasar pemikiran peneliti serta peneliti menambahkan satu aspek lagi, yaitu aspek verbalisasi positif, dengan prinsip introspeksi atau self report, yaitu laporan tentang diri sendiri. Setelah dilakukan analisis terhadap data uji coba (try out), diperoleh koefisien korelasi item total bergerak antara 0,0197 sampai 0,8054 dan koefisien alpha 0,9531 .

Pengambilan data pada penelitian ini dilakukan sebelum dan sesudah proses pelatihan. Jika selama kegiatan tersebut ada subjek yang tidak hadir atau tidak mengikuti kegiatan maka dianggap gugur atau tidak diikutkan dalam perhitungan.

\section{Intervensi}

Pelatihan ini merupakan suatu kegiatan yang terdiri dari keteraturan membaca dan menghayati makna ayat dalam Al-Quran. Pelatihan dilakukan dengan membaca Al-Quran 
yang dilakukan setiap hari secara konsisten, teratur dan berkesinambungan dalam kehidupan sehari-hari selama 30 hari serta menghayati makna ayat dalam Al-Quran yang dipandu oleh seorang ustadz seminggu sekali.

Materi pelatihan ini ditentukan oleh tiga orang Ustadz, yaitu UstadzAlfi Syahar, Ustadz Maulidi dan Ustadz Supriyanto Pasir, serta dibuat dan disampaikan oleh tiga orang Ustadz tersebut.

Jadwal Pengkajian Al-Quran diatur dalam tabel 1 sebagai berikut:

Tabel 1. Jadwal Pengkajian Al Qur'an

\begin{tabular}{cllc}
\hline Pertemuan & \multicolumn{1}{c}{ Materi } & Hari/Tanggal & Waktu \\
\hline I & Tafsir QS. Al-Fatihah : 1-7 & Sabtu,17 Mei'08 & $09.00-11.00$ WIB \\
II & Tafsir QS. Al-Insyirah : 1-8 & Sabtu,24 Mei'08 & $09.00-11.00$ WIB \\
III & Tafsir QS. Al-Ma'un : 1-7 & Sabtu,31 Mei'08 & $09.00-11.00$ WIB \\
IV & QS. Al-Baqoroh : 1-5 dan 21-25 & Sabtu,07 Juni'08 & $09.00-11.00$ WIB \\
\hline
\end{tabular}

\section{Metode Analisis Data}

Pengujian hipotesis dalam penelitian ini menggunakan teknik uji t dari program SPSS versi 11.5 for windows.

\section{Hasil Penelitian}

Penelitian ini dilakukan dalam beberapa kali kegiatan membaca dan memaknai Al Qur'an dengan bimbingan tiga ustadz. Pertemuan pertama dilaksanakan pada tanggal $17 \mathrm{Mei}$ 2008 dimulai pada pukul 09.00 WIB. Peneliti sudah hadir 90 menit sebelum waktu pelaksanaan, guna mengecek agenda membaca Al-Quran subjek penelitian serta meminta izin memanggil seluruh subjek penelitian menuju ruang aula yang letaknya terpisah dari ruang tahanan dan mempersiapkan tempat serta makalah tafsir dan lembaran QS. Al-Fatihah: 1-7.

Pada pertemuan pertama terdapat tiga subjek yang gugur, yaitu subjek satu, lima dan delapan karena tidak membaca Al-Quran secara teratur. Subjek penelitian datang pukul 08.55 WIB. Sebelum penelitian dimulai peneliti mempersilakan subjek untuk menempati tempat duduk yang telah dipersiapkan dengan posisi melingkar.

Pertemuan dibuka oleh MC pada pukul 09.07 WIB dengan mengucapkan salam, sambutan, dan memperkenalkan ustadz. Pukul 09.13 WIB kegiatan dimulai. Ustadz Alfi Syahar membacakan QS. Al-Fatihah ayat 1-7 dengan suara yang lantang. Selanjutnya, ustadz membimbing peserta untuk membaca secara bergantian dimulai dari subjek yang 
duduk disebelah kanan ustadz. Setelah seluruh peserta selesai membaca QS. Al-Fatihah ayat 1-7, ustadz mulai memberikan tafsir QS. Al-Fatihah ayat 1-7. Pada saat ustadz memberikan materi subjek terlihat antusias menyimak materi yang disampaikan. Beberapa di antara mereka ada yang mulai mengajukan pertanyaan meskipun sesi tanya jawab belum dibuka. Ustadz berusaha menjawab setiap pertanyaan yang diajukan. Sesi tanya jawab terus saja berjalan melampaui waktu yang telah ditetapkan. Karena subjek harus mengikuti sholat dzuhur berjamaah dan pergantian petugas penjaga, maka dengan tidak mengurangi rasa hormat sesi tanya jawab segera diakhiri. Pengkajian Al-Quran diakhiri dengan ustadz membacakan kembali QS. Al-Fatihah ayat 1-7 dan seluruh subjek penelitian diminta untuk mengikutinya, lalu ditutup dengan pembacaan doa.

Pertemuan kedua dilaksanakan pada tanggal 24 Mei 2008. Peneliti sudah hadir 60 menit sebelum waktu pelaksanaan, guna mengecek agenda membaca Al-Quran subjek penelitian serta meminta izin memanggil seluruh subjek penelitian menuju ruang aula dan mempersiapkan tempat serta makalah tafsir dan lembaran QS. Al-Insyirah ayat 1-8. Pada pertemuan kedua terdapat dua subjek yang gugur yaitu subjek dua dan subjek 10 karena dipindahkan ke Lembaga Pemasyarakatan Khusus Narkotika di Pakem sejak tanggal $19 \mathrm{Mei}$ 2008. Subjek sembilan juga digugurkan karena tidak membaca Al-Quran secara teratur. Pada saat subjek keempat tiba, subjek memberikan rangkuman materi dan pertanyaan pada pertemuan pertama kepada peneliti.

Materi dimulai pada pukul 09.03WIB. UstadzAlfi Syahar membacakan QS. Al-Insyirah ayat 1-8 kemudian meminta peserta untuk membaca QS. Al-Insyirah ayat 1-8 secara bergantian dimulai dari subjek yang duduk di sebelah kanan ustadz. Setelah seluruh peserta selesai membaca QS. Al-Insyirah ayat 1-8, ustadz memberikan tafsir QS. Al-Insyirah ayat 1-8 yang telah dibaca dilanjutkan dengan tanya jawab. Setelah sesi tanya jawab selesai ustadz membimbing subjek penelitian untuk membaca QS. Al-Insyirah ayat 1-8 dan subjek diminta untuk mengikutinya, kemudian ditutup dengan pembacaan doa. Pada Pertemuan kedua ini diberikan lembar evaluasi mengenai pelaksanaan pengkajian Al-Quran.

Pertemuan ketiga dilaksanakan pada tanggal 31 Mei 2008. Peneliti sudah hadir 45 menit sebelum waktu pelaksanaan, guna mengecek agenda membaca Al-Quran subjek penelitian serta meminta izin memanggil seluruh subjek penelitian menuju ruang aula dan mempersiapkan tempat serta makalah tafsir dan lembaran QS. Al-Ma'un : 1-7.

Pada pertemuan ketiga terdapat satu subjek yang gugur, yaitu subjek lima karena tidak membaca Al-Quran secara teratur. Pada saat subjek keempat tiba, subjek memberikan lagi rangkuman materi dan pertanyaan pada pertemuan kedua kepada peneliti. Materi dimulai 
pada pukul 09.09 WIB. Ustadz Maulidi membacakan QS. Al-Ma'un ayat 1-7, kemudian membimbing peserta untuk membaca QSAI-Ma'un : 1-7 secara bergantian dimulai dari subjek yang duduk di sebelah kanan ustadz. Setelah seluruh peserta selesai membaca QS. Al-Ma'un ayat 1-7, ustadz memberikan tafsir QS. Al-Ma'un : 1-7 yang telah dibaca dan dilanjutkan dengan tanya jawab. Ustadz membimbing membaca QS. Al-Ma'un : 1-7 kemudian diikuti oleh seluruh peserta, pengkajian ditutup dengan pembacaan doa.

Pertemuan keempat dilaksanakan pada tanggal 07 Juni 2008. Peneliti sudah hadir 60 menit sebelum waktu pelaksanaan, guna mengecek agenda membaca Al-Quran subjek penelitian serta meminta izin memanggil seluruh subjek penelitian menuju ruang aula dan mempersiapkan tempat, makalah tafsir dan lembaran QS. AI-Baqoroh ayat 1-5 dan 21-25.

Materi mulai disampaikan pada pukul 09.05 WIB. Ustadz Supriyanto Pasir membacakan QS. Al-Baqoroh ayat 1-5 dan 21-25, kemudian membimbing peserta membaca QS. Al-Baqoroh ayat 1-5 dan 21-25 secara bergantian dimulai dari sisi sebelah kanan ustadz. Setelah seluruh peserta selesai membaca QS. Al-Baqoroh ayat 1-5 dan 21-25, ustadz memberikan tafsir QS. Al-Baqoroh ayat 1-5 dan 21-25 yang telah dibaca dilanjutkan dengan sesi tanya jawab. Ustadz membimbing membaca QS. Al-Baqoroh ayat 1-5 dan 21-25 dan diikuti oleh subjek penelitian dan ditutup dengan pembacaan doa yang dipimpin oleh ustadz.

Pada pertemuan terakhir ini peneliti memberikan lembar evaluasi mengenai pelaksanaan pengkajian Al-Quran. Setelah acara pelatihan selesai subjek keempat memberikan lagi rangkuman materi dan pertanyaan pada pertemuan ketiga kepada peneliti dan meminta agar pelatihannya tetap dilanjutkan.

\section{DeskripsiData Penelitian}

Hasil uji normalitas dan homogenitas menunjukkan bahwa data subjek homogen dan linier.

Tabel 2. Hasil Uji Normalitas

\begin{tabular}{lccc}
\hline \multicolumn{1}{c}{ Kelompok } & Skor K-SZ & $\mathrm{p}$ & Kategori \\
\hline Prates Eksperimen & 0,438 & 0,991 & Normal \\
Prates Kontrol & 0,630 & 0,822 & Normal \\
Pascates Eksperimen & 0,426 & 0,993 & Normal \\
Pascates Kontrol & 0,570 & 0,901 & Normal \\
\hline
\end{tabular}


Tabel 3. Hasil Uji Homogenitas

\begin{tabular}{lccc}
\hline \multicolumn{1}{c}{ Kelompok } & Levene Statistics & $\mathrm{P}$ & Kategori \\
\hline Prates & 0,159 & 0,700 & Homogen \\
Pascates & 0,140 & 0,717 & Homogen \\
\hline
\end{tabular}

Tabel 4. Prates Kelompok Eksperimen-Kontrol

\begin{tabular}{cccccc}
\hline Kelompok & $\mathrm{N}$ & Minimum & Maksimum & Mean & Std. Deviation \\
\hline KE & 3 & 150 & 165 & 156,67 & 7,638 \\
KK & 8 & 150 & 181 & 161,13 & 9,906 \\
\hline
\end{tabular}

Nilai $p$ sebesar 0,496 , berarti $p>0,05$, sehingga dapat disimpulkan bahwa keadaan awal seluruh subjek penelitian baik pada kelompok eksperimen maupun kontrol berada pada kondisi yang sama atau tidak ada perbedaan.

Tabel 5. Gains Score

\begin{tabular}{cccccc}
\hline Kelompok & $\mathrm{N}$ & Minimum & Maksimum & Mean & Std. Deviation \\
\hline KE & 3 & 160 & 183 & 13,67 & 4,041 \\
KK & 8 & 144 & 175 & $-5,13$ & 4,734 \\
\hline
\end{tabular}

Nilai $p$ sebesar 0,0125 , berarti nilai $p<0,05$, sehingga dapat disimpukan bahwa terdapat perbedaan yang signifikan antara kelompok eksperimen dan kontrol.

Tabel 6. Prates-Pascates Kelompok Eksperimen

\begin{tabular}{lccccc}
\hline Kelompok & $\mathrm{N}$ & Minimum & Maksimum & Mean & Std. Deviation \\
\hline Prates & 3 & 150 & 165 & 156,67 & 7,638 \\
Pascates & 3 & 160 & 183 & 170,33 & 11,676 \\
\hline
\end{tabular}

Uji t terhadap kelompok eksperimen menghasilkan nilai p sebesar 0,0545 , berarti nilai $p>0,05$, hal ini menunjukkan bahwa tidak ada perbedaan yang signifikan antara sebelum dan sesudah mengikuti pelatihan keteraturan membaca dan menghayati makna ayat dalam AlQuran pada kelompok eksperimen. 
Tabel 7. Prates-Pascates Kelompok Kontrol

\begin{tabular}{lccccc}
\hline Kelompok & $\mathrm{N}$ & Minimum & Maksimum & Mean & Std. Deviation \\
\hline Prates & 8 & 151 & 181 & 161,13 & 9,906 \\
Pascates & 8 & 144 & 175 & 156,00 & 9,457 \\
\hline
\end{tabular}

Uji t terhadap kelompok kontrol menunjukkan nilai $p$ sebesar 0,009 , berarti nilai $p<0,05$, sehingga dapat disimpulkan bahwa terdapat perbedaan yang sangat signifikan antara prates dan pascates.

Berdasarkan hasil analisis di atas, dapat diketahui bahwa ada pengaruh positif yang signifikan antara keteraturan membaca dan menghayati makna ayat dalam Al-Quran terhadap kemampuan berpikir positif pada narapidana. Narapidana yang mengikuti pelatihan keteraturan membaca dan menghayati makna ayat dalam Al-Quran memiliki kemampuan berpikir positif yang lebih tinggi daripada yang tidak mengikuti pelatihan. Dengan demikian hipotesis yang diajukan penulis diterima.

\section{Pembahasan}

Penelitian ini bertujuan untuk menguji hipotesis tentang adanya pengaruh keteraturan membaca dan menghayati makna ayat dalam Al-Quran terhadap kemampuan berpikir positif pada narapidana. Hasil analisis data kuantitatif menunjukkan bahwa ada perbedaan kemampuan berpikir positif yang signifikan antara sebelum dan sesudah pelatihan keteraturan membaca dan menghayati makna ayat dalam Al-Quran. Hal ini ditunjukkan dari adanya peningkatan skor berpikir positif pada kelompok eksperimen setelah mengikuti pelatihan.

Peningkatan berpikir positif yang terjadi pada kelompok eksperimen diyakini karena mendapat pengaruh dari pelatihan keteraturan membaca dan pengkajian Al-Quran, bukan karena pengaruh faktor lain, seperti perbedaan kondisi antara kelompok eksperimen dan kontrol. Kondisi antara kelompok eksperimen dan kontrol sebelum pelatihan setara sehingga kedua kelompok berangkat dari titik tolak yang sama. Dengan demikian kondisi kelompok pra eksperimen tidak menjadi faktor terjadinya perbedaan berpikir positif kedua kelompok. Hal ini ditunjukkan dari nilai prates kelompok eksperimen dan kontrol dengan nilai p sebesar 0,496 , berati $p>0,05$, sehingga dapat disimpulkan bahwa keadaan awal seluruh subjek penelitian baik pada kelompok eksperimen maupun kontrol berada pada kondisi yang sama atau tidak ada perbedaan. 
Pendekatan belajar-pesan (message-learning approach) menyatakan bahwa proses yang paling dasar dalam pengubahan sikap manusia adalah atensi, pemahaman, penerimaan dan retensi (Azwar, 2007). Keempat-empatnya merupakan proses perantara internal yang dipengaruhi oleh karakteristik sumber pesan (ustadz), pesan itu sendiri (materi), target atau orang yang sikapnya yang hendak diubah (subjek penelitian), dan saluran yang digunakan dalam penyampaian dan penerimaan pesan (metode penyampaian).

Ketiga subjek penelitian yang memiliki peningkatan skor berpikir positif setelah mengikuti pelatihan keteraturan membaca dan menghayati makna ayat dalam Al-Quran memiliki interaksi positif terhadap sumber, pesan, target dan saluran. Sumber pesan memiliki pengaruh kuat terhadap subjek sehingga menimbulkan perhatian subjek terhadap pesan yang disampaikan. Perhatian terhadap pesan menimbulkan pemahaman. Perhatian dan pemahaman tersebut merubah keyakinan subjek yang awalnya berpikiran negatif berubah menjadi berpikiran positif.

Keberhasilan yang dialami masing-masing subjek cukup bervariasi, terbukti dengan adanya peningkatan skor berpikir positif yang dicapai subjek, yang tidak seragam pada tiap subjek. Menurut Cohen dan Milgram (Sukmana, 2003), manusia mempunyai kemampuan yang terbatas dalam memproses berbagai informasi yang berasal dari lingkungan. Keterbatasan dalam memproses rangsang masing-masing individu tidak sama. Subjek pelatihan memiliki kemampuan yang berbeda dalam menerima materi. Ada yang dapat menerima secara utuh dan ada yang sebagian. Perbedaan keterbatasan itulah yang menyebabkan pengolahan informasi menjadi tidak maksimal.

Kekuatan subjek dalam menerima informasi juga terbatas. Perhatian individu terhadap rangsang tidak bersifat konstan dan mungkin selama beberapa waktu tertentu hilang (Cohen, dalam Sukmana, 2003). Kondisi yang dijelaskan Cohen tersebut sama dengan yang terjadi pada subjek pelatihan. Hal tersebut tampak pada variasi skor berpikir positif subjek penelitian.

Uji t terhadap kelompok eksperimen menghasilkan nilai p sebesar 0,0545 , berarti nilai $p>0,05$. Hal ini menunjukkan bahwa tidak ada perbedaan yang signifikan antara sebelum dan sesudah mengikuti pelatihan keteraturan membaca dan menghayati makna ayat dalam AlQuran pada kelompok eksperimen.

Uji t terhadap kelompok kontrol menunjukkan nilai $p$ sebesar 0,009 , berarti nilai $p<$ 0,05 , sehingga dapat disimpulkan bahwa terdapat perbedaan yang sangat signifikan antara prates dan pascates.

Hasil dari penelitian ini membuktikan bahwa keteraturan membaca dan menghayati makna ayat dalam Al-Quran merupakan salah satu cara yang dapat digunakan untuk dapat 
meningkatkan kemampuan berpikir positif. Hal ini sejalan dengan penelitian yang dilakukan oleh Puspasari (1997) yang meneliti tentang hubungan antara religiusitas dengan berpikir positif pada remaja. Hasil penelitiannya menunjukkan bahwa terdapat hubungan yang positif dan sangat signifikan antara religiusitas dengan berpikir positif pada remaja. Semakin tinggi religiusitas maka semakin tinggi pula berpikir positifnya.

Berdasarkan uraian di atas dapat disimpulkan bahwa setelah mengikuti pelatihan keteraturan membaca dan menghayati makna ayat dalam Al-Quran ada peningkatan kemampuan berpikir positif. Ini berarti dapat ditarik kesimpulan bahwa ada pengaruh positif yang signifikan antara keteraturan membaca dan menghayati makna ayat dalam Al-Quran terhadap kemampuan berpikir positif pada narapidana. Narapidana yang mengikuti pelatihan memiliki kemampuan berpikir positif lebih tinggi daripada narapidana yang tidak mengikuti pelatihan.

Ada beberapa kelemahan yang terdapat dalam penelitian ini, di antaranya adalah pemilihan subjek yang ditentukan oleh pihak Lembaga Pemasyarakatan. Ada subjek penelitian yang merasa terpaksa mengikuti pelatihan. Persiapan pelaksanaan pelatihan keteraturan membaca dan menghayati makna ayat dalam Al-Quran yang kurang matang meliputi pemilihan waktu yang bertabrakan dengan jam besuk sehingga memecah perhatian subjek, tempat penelitian yang kurang kondusif karena digunakan pula untuk urusan persidangan. Di samping itu, materi tidak bisa disampaikan oleh ustadz yang sama karena terkendala dengan kesibukan ustadz.

Selain itu kelemahan dalam penelitian ini adalah skala yang digunakan untuk mengukur tingkat berpikir positif yakni item-item dalam berpikir positif tidak secara spesifik menyebutkan berpikir positif pada narapidana.

\section{Simpulan dan Rekomendasi}

Hasil penelitian ini menunjukkan bahwa keteraturan membaca dan menghayati makna ayat dalam Al-Quran mempunyai pengaruh positif yang signifikan terhadap kemampuan berpikir positif pada narapidana. Narapidana yang mengikuti pelatihan keteraturan membaca dan menghayati makna ayat dalam Al-Quran memiliki kemampuan berpikir positif yang lebih tinggi daripada narapidana yang tidak mengikuti pelatihan keteraturan membaca dan menghayati makna ayat dalam Al-Quran.

Hasil penelitian menunjukkan bahwa terdapat peningkatan berpikir positif pada narapidana, sehingga diharapkan untuk menerapkannya dalam kehidupan sehari-hari. Bagi pihak Lembaga Pemasyarakatan Kelas II A Yogyakarta diharapkan dapat memberikan 
bimbingan keagamaan kepada narapidana dan membuat kurikulum keteraturan membaca dan menghayati makna ayat dalam Al-Quran. Saran yang dapat diberikan untuk narapidana adalah membiasakan diri membaca AI-Qur'an dan berupaya memahami maknanya.

\section{DAFTAR PUSTAKA}

Albrecht, K. 2005. Daya Pikir : Metode Peningkatan Potensi Berpikir. (R.D. Praty, Penerjemah). Semarang: Dahara Prize.

Anonim. Tanpa Tahun. Belajar Agama di LP Cipinang. Diunduh pada $06 \mathrm{Mei}, 2008$, dari http://www.hamline.edu/apakabar/basisdata/1996/03/0009.html.

Anonim. Tanpa Tahun. 'Islam Telah Merubahku...' Fahril, Anggota Sahabat Napi. Diunduh pada 06 Mei, 2008, dari http://baitulmaalhidayatullah.com/content/view/89/99/.

Azwar, S. 2007. Sikap Manusia : Teori dan Pengukurannya. Yogyakarta : Pustaka Pelajar.

Hawari, D. 2002. Dimensi Religi dalam Praktek Psikiatri dan Psikologi. Jakarta: Balai Penerbit Fakultas Kedokteran Universitas Indonesia.

Priyatno, D. 2006. Sistem Pelaksanaan Pidana Penjara di Indonesia. Bandung: PT Refika Aditama.

Puspasari, L. 1997. Hubungan Antara Religiusitas dengan Berpikir Positif pada Remaja. Skripsi , tidak diterbitkan, Yogyakarta: Fakultas Psikologi UGM.

Rahayu, I. T. 2004. Pengaruh Pelatihan Pengembangan Diri Terhadap Peningkatan Berpikir Positif dan Penurunan Kecemasan Berbicara di Depan Umum. Tesis, tidak diterbitkan, Yogyakarta: Fakultas Psikologi UGM.

Sujatno, A. Tanpa tahun. Pencerahan di Balik Penjara (Bagian I). Diunduh pada $31 \mathrm{Mei}, 2008$, dari http://www.ditjenpas.go.id/index.php?option $=c o m \_c o n t e n t \& t a s k=$ view\&id $=178 \&$ temid $=9$.

Sukmana, O. 2003. Dasar-DasarPsikologi Lingkungan. Yogyakarta: UMM Press.

Zuhroni. 2003. Islam untuk Disiplin IImu Kesehatan dan Kedokteran 2. Jakarta. Direktorat Jenderal Kelembagaan Agama Islam. 